Marquette University

e-Publications@Marquette

Economics Faculty Research and Publications

Economics, Department of

$1-1-2000$

\title{
The United States and Global Capital Markets
}

Joseph P. Daniels

Marquette University, joseph.daniels@marquette.edu

Published version. "The United States and Global Capital Markets," in Globalizing America: The USA in World Integration. Thomas L. Brewer and Gavin Boyd. Cheltenham, ENG: Edward Elgar Publishing, 2000: 154-172. Publisher Link. (c) 2000 Edward Elgar Publishing. Used with permission. 


\section{The United States and global capital markets}

\section{Joseph P. Daniels}

\section{INTRODUCTION}

During the Bretton Woods period, central banks were responsible for maintaining pegged exchange values thereby reducing exchange rate risk and currency arbitrage opportunities. The existence of significant capital controls made sovereign governments and international agencies the primary source of official development financing. The ad hoc system of flexible exchange rates that emerged in 1973 through 1976 resulted in a transfer of exchange rate risk, and arbitrage opportunities, from government agencies to the private sector. The dismantling of capital controls and deregulation of domestic financial sectors signalled a willingness of governments to substitute private sector financing for official financing by domestic governments and international agencies.

Liberalization of capital markets, along with increased international transactions in the real sector, have spurred dramatic growth in the international money and capital markets. (See Williamson and Mahar (1998) for an excellent essay on financial liberalization.) Daily foreign exchange transactions, for example, have grown to nearly $\$ 1.4$ trillion. This growth highlights the importance of today's capital markets in allocating savings worldwide. By channelling savings to borrowers, capital market institutions help finance domestic investment and direct savings, whether it be domestically and globally, to their most efficient use, allowing savers to achieve higher risk adjusted rates of return. Access to global capital markets allows borrowers to pursue investment projects in times of domestic downturns, thus reducing domestic business cycles (Eichengreen et al., 1999). In light of recent financial crises, however, many observers have come to question the benefits of uninhibited international capital flows and its contribution to real sector investment.

Eatwell and Taylor (1998) argue that the performance of the financial sector must ultimately be judged on its contribution to the real sector in terms of long-run trends in employment and growth. In this regard they make two important observations. First, trend growth of the G7 economies has slowed 
to two-thirds of the rate posted in the 1960s. Second, there is disagreement as to whether the performance of financial institutions affects medium or long-term trend performance of the real sector or if it is determined solely by structural aspects of the real sector.

It is assumed here that the performance of capital markets and financial institutions is important for real sector outcomes as it affects public and private sector behaviour. Hence, a solvent and sound system of financial institutions may promote continued domestic growth and prosperity. Under unstable conditions, however, intermediaries may channel capital flows in a way that 'undermine domestic policies' (Crockett, 1997, p. 7), triggering a financial crisis.

The potential costs of these financial crises is abundant. For example, it is believed that the costs of the 1980s banking crises in Argentina equalled one-half of the nation's GDP while the United States' bailout of banks during the early 1990s totalled at least $\$ 200$ billion. The 1995 real estate collapse in Japan resulted in the non-performance of more than $\$ 250$ billion in bank loans. In South Korea more than 10 per cent of all bank loans are non-performing. For India and China non-performing loans are estimated to be nearly 20 per cent of outstanding loans. Since 1980, the IMF estimates that 133 of 181 IMF member nations have suffered banking problems it considers to be 'significant' (Lindgren et al., 1996).

Further, as has been seen in recent financial crises, banking solvency is critical to the operation and stability of the global economy as well. How should sovereign governments and international organizations respond to this issue? One view is that financial intermediation is inherently an unstable business the fortunes of which rise and fail with the business cycle. Hence, government regulation and safety nets are required to prevent periodic banking collapses. Another view is that safety nets themselves create a moral hazard problem and may actually be responsible for recent banking crises. Regardless of the view taken, it is important to ensure that global capital markets operate as efficiently as possible. As capital markets become more integrated internationally, therefore, the need for stability, solvency and regulation becomes paramount as financial crises can be magnified.

This chapter considers these issues, focusing on institutions, market structure and growth, and risk. The next section considers the basic rationales for, and characteristics of, financial intermediation with attention given to the unique characteristics of the United States in financing capital investment projects. The section after that highlights recent developments in world financial markets, distinguishing between the money and capital markets, and examines the most important development, the increase in capital flows to developing markets. The next section explores various sources of risks and examines opposing views on regulation, presents recent attempts and propos- 
als for global regulation and questions whether new or old institutions are best suited to supervise intermediation. The final section offers a conclusion.

\section{RATIONALES FOR, AND CHARACTERISTICS OF, FINANCIAL INTERMEDIATION}

Financial transactions can be direct or indirect. For example, households may allocate wealth to the purchase of a bond issued by a company, effectively making a direct loan to that business. In this way, households assist in the direct finance of domestic capital investment projects. It is also possible that a household may obtain a long-term time deposit at a banking firm. In turn, the bank may allocate these funds, together with those of other deposit holders, to holdings of bonds issued by the same company as before. In this instance, the household would indirectly finance domestic capital investment. The bank, in turn, intermediates the financing of the domestic investment. The process of indirect finance, or financial intermediation, is the most common way in which funds are channelled from saving to investment and the financial institutions that fulfil this role are called financial intermediaries.

\section{The Rationales for Domestic and International Financial Intermediation}

One rationale for the use of intermediaries is the existence of asymmetric information. Often lenders are not privy to all of the pertinent information about the borrower and the investment project, particularly information about risk. The existence of asymmetric information can lead to adverse selection, or the potential for those who desire funds for unworthy projects to be the most likely to want to borrow or to issue debt instruments. A result of adverse selection is that the issuance of poor-quality instruments can make savers less willing to lend to or hold debt instruments issued by those seeking to finance high-quality projects. Also, poor market information or uncertainty about the competence of the financial intermediaries' market may result in herding behaviour; that is, when savers follow the behaviour of someone they feel is better informed, leading to self-fulfilling outcomes. High-quality banking institutions may minimize herding behaviour by depositors.

A third problem that financial market participants face is moral hazard. Moral hazard is the potential that, after they have access to funding, a borrower might engage in behaviour that increases risk - or, in other words, the 'immoral' behaviour, from the lender's perspective, that the borrower would thereby have exhibited. Moral hazard is the primary argument used against the recent financial support arrangements offered by the IMF and G7 nations, and used to argue in favour of debt restructuring schemes that involve private 
sector bondholders. Another important reason for agents to use financial intermediaries is economies of scale. Financial intermediaries make it possible for individuals to pool funds together, increasing the scale of possible opportunities. In addition, this centralization of management can reduce the average fund management costs below the level an individual would incur.

Financial intermediaries, therefore, exist to save holders of financial instruments from incurring risks and allow them to enjoy reduced costs as described above. While these institutions cannot eliminate adverse selection, herding behaviour and moral hazard problems, they can collect information, at a lower marginal cost, about the underlying riskiness of financial instruments and monitor the continuing performance of those who issue such instruments, thereby reducing the extent of adverse selection and moral hazard problems in the market for these bonds.

The rationales for international financial intermediation are the same as for domestic intermediation. For example, asymmetric-information problems are likely to be at least as severe when evaluating the riskiness of foreign financial instruments as compared to domestic instruments, and therefore the need for international financial intermediation is greater. Banks located in various countries take part in the process of international financial intermediation by using some of the funds of domestic deposit holders to finance loans to individuals and companies based in other nations. Most of this international banking activity takes place in the Eurocurrency markets. Today, very few nations' capital investment projects are purely domestically financed. Even bank-financed investment in the United States increasingly stems from loans by non-US banks, with the largest US corporations on average using the services of more foreign banks as compared with the average number of domestic institutions whose services they utilize.

As shown in Table 7.1, the world's largest banking institutions, sometimes referred to as 'megabanks', tend to be located outside of the United States. By increasing their asset portfolios through regional or world-wide expansion, megabanks may reduce average operating costs, gaining efficiency. The evidence for economies of scale in banking is more mixed for US banks than for their European counterparts, even though US bank managers themselves commonly offer economies of scale as a key rationale for large-scale mergers in the United States.

\section{National Characteristics of Intermediation}

There are several ways in which countries' banking systems and the use of banks and market finance differ. The first is the extent to which domestic firms use foreign banks relative to domestic banks. US multinationals tend to rely on foreign banking institutions to intermediate investment projects to a 
Table 7.1 The largest banks

\begin{tabular}{lcc}
\hline Bank & Country & Assets (US\$ billions) \\
\hline Tokyo Mitsubishi Bank & Japan & 692 \\
Deutsche Bank AG & Germany & 580 \\
Sumitomo & Japan & 484 \\
Credit Suisse Group & Switzerland & 474 \\
HSBC Holdings & United Kingdom & 471 \\
Dai-Ichi Kangyo Bank & Japan & 433 \\
Sanwa Bank & Japan & 428 \\
Credit Agricole Mutuel & France & 420 \\
Fuji Bank & Japan & 414 \\
ABN Amro Holdings & The Netherlands & 412 \\
\hline
\end{tabular}

Note: Based on total assets held on 31 December 1997.

Source: American Banker, 6 August 1998.

much higher degree than multinationals of other nations. By the 1990s, for example, a typical multinational US firm had accounts with at least as many banks abroad as they maintained with US-based banking institutions.

Another aspect in which national banking systems differ concerns the extent to which banks are the predominant means by which firms finance their working capital needs. For instance, British, German and Japanese businesses use bank loans to finance significantly larger shares of their investment as compared with businesses located in the United States. In the United Kingdom, nearly 70 per cent of funds raised by businesses typically stem from bank borrowings. The proportions for Germany and Japan were of the order of 50 per cent and 65 per cent, respectively. In contrast, US businesses normally raise fewer than 30 per cent of their funds through bank loans. This difference helps to explain why German and Japanese banks more than doubled their size between the 1970s and the 1990s. Though British banks grew by less in relative terms, their importance in British business finance permitted them to grow faster than US banks, whose overall size, adjusted for inflation, failed to change significantly in the two decades following the 1970s.

There also are differences in market structures across nations. In particular, the extent of potential rivalry, often measured by the portion of total deposits concentrated within a nation's largest banks, can vary considerably. The top five banks in Belgium, Denmark, France, Italy, Luxembourg, Portugal, Spain and the United Kingdom have over 30 per cent of the deposits of their 
nations' residents. In Greece and the Netherlands, this figure is over 80 per cent. In contrast, the top five US banks account for fewer than 15 per cent of the deposit holdings of US residents. With regard to total bank assets, the US banking system also appears to exhibit more potential for rivalry among its banks, as less than a third of total bank assets are concentrated among the top ten US banks. In Germany, Japan and the United Kingdom, this figure is about two-thirds.

The degree of banking competition within a nation also depends on how open the nation's borders are to rivalry from foreign-based banking operations. By the early 1990s, foreign banks made many loans to US individuals and firms, but foreign banks had barely penetrated the German and Japanese loan markets. This undoubtedly has played a role in producing the high levels of bank asset concentration in Europe and Japan, as shown in Table 7.1.

Another feature that distinguishes national banking systems is the extent to which they permit universal banking, under which there are few if any limits on the ability of banks to offer full ranges of financial services and to own equity shares in corporations. In Germany and the United Kingdom, as well as in several other European nations, banks face few such restrictions. Japanese banks face greater restrictions on their activities, but many Japanese banks have the authority to underwrite stocks and bonds. By contrast, in the United States universal banking has been prohibited since 1933, when the US Congress passed the Glass-Steagall Act. There has been little evidence that banks in nations with universal banking are significantly more risky than their US counterparts; one of the common arguments against universal banking. The purchase of Bankers Trust by Deutsche Bank in 1998 highlights how disadvantaged US banks are internationally and helped put the removal of the Glass-Steagall Act back on the congressional agenda in 1999.

The legal environment, the level of diversification and the degree of competition are characteristics which are highly interdependent, making it difficult to delineate the cause and effect of market outcomes. The result for the United States is that US firms rely on foreign banks to a greater extent than do their foreign counterparts, yet rely on bank financing to a significantly lesser degree overall. Some nations protect their banking industries to a higher degree while allowing them to compete in a broader range of services. The German and Japanese systems of banks, therefore, tend to have fewer institutions, each with a much larger degree of market concentration.

Some key observations can be made at this point. First, soundness of domestic banking systems is important for the efficient channelling of savings to productive investment projects, and for the heavy costs that banking crises can entail. Second, because US firms rely on foreign banking institutions to such a high degree, the soundness and solvency of foreign banks is important to US business managers and policy-makers. Finally, because of 
the extent to which US firms rely on direct intermediation to finance investment projects, managers and policy-makers must be concerned with the reliability and stability of domestic and global capital markets.

In regard to the first observation, the questions faced by US policy-makers are: to what extent should concentration be allowed, at the risk of reduced domestic competition; what services should banks be allowed to compete in; and what, if anything, should be done to enhance the global competitiveness of US banking institutions. To some degree these have been answered, as technological advancements, deregulation efforts in the 1980s and increased willingness for mergers and acquisitions have slowly eroded the restrictions placed on US banks through dual-system regulations and the Glass-Steagall Act. Now that these important financial institutions have been considered, we next examine how global financial markets have evolved.

\section{WORLD FINANCIAL MARKETS}

Following the end of World War II, the industrialized nations pursued a goal of greater trade liberalization. Not until the 1970s, however, did most industrialized nations begin to liberalize financial markets. Changes in communications technology combined with the introduction of innovative new financial instruments has moved even reluctant nations to liberalize and deregulate their financial markets. The advent of instant and low-cost communications and information innovations allows a wider range of firms and individuals to participate in international financial markets and to manage their risk exposure more effectively. As a result, since the 1970 s the growth of international financial markets has far outpaced the growth of international trade in goods and services. Savers, as discussed below, have yet to take full advantage of these new opportunities. This stylized fact, combined with the usual econometric evidence on parity conditions, indicates that though capital markets have become more integrated, they are far from perfectly integrated.

\section{International Capital Markets}

International capital markets are the markets for cross-border exchange of financial instruments which have a maturity of a year or more, or with no distinct maturity. Table 7.2 presents evidence on the dramatic growth of issues in the international capital markets. Between 1986 and 1996 total financing activity that took place on the international capital markets increased by $\$ 526.7$ billion, or 219.6 per cent.

Table 7.2 separates the data into two of its most important components: international bonds and international equities. A third component of the 
Table 7.2 Growth of the international capital market (US\$ billions)

\begin{tabular}{lrrrc}
\hline & 1986 & 1997 & Change & Percentage change \\
\hline Total & 389.5 & 1769.3 & 1379.8 & 354.2 \\
Securities & 195.5 & 916.7 & 721.2 & 368.9 \\
Loans & 88.5 & 390.4 & 301.9 & 341.1 \\
\hline
\end{tabular}

Source: Organization for Economic Cooperation and Development, Financial Market Trends.

international capital markets is foreign direct investment. The international bond market, which represents 92 per cent of the international capital markets, experienced the greatest absolute growth, with an increase of $\$ 480.7$ billion. The international equities market, on the other hand, experienced the most rapid rate of growth with a fivefold increase over the 10-year period.

The impact of increased participation of institutional investors has been given much attention of late. Deregulation, liberalization and the technological advances described earlier create a wider range of savings opportunities for individuals through institutional investors. A recent study by the OECD (1997) details the size and growth of financial instruments managed by institutional investors. Table 7.3 presents the OECD's data for the six nations with the largest institutional investor activity. As shown, the United States and the United Kingdom are two of the nations with the greatest amount of institutional investor activity. The table also shows that between 1990 and 1995 the financial assets of institutional investors increased by one-third to one-half for the United States, the United Kingdom and Canada.

Even though the development and growth of the international capital market allows individuals and businesses greater opportunities to manage risk and increase potential returns, savers do not utilize the international capital

Table 7.3 Financial assets of institutional investors (\%GDP)

\begin{tabular}{lrc}
\hline & 1995 & Percentage change 1990-95 \\
\hline Canada & 87.9 & 50.0 \\
Luxembourg & 2132.8 & 0 \\
Netherlands & 158.4 & 18.7 \\
Sweden & 114.8 & 34.4 \\
United Kingdom & 162.3 & 41.7 \\
United States & 170.8 & 34.1 \\
\hline
\end{tabular}

Source: Organization for Economic Cooperation and Development, Financial Market Trends. 
market to the extent we might expect. French and Poterba (1991) find that savers demonstrate a low level of international diversification in their portfolios and that most corporate equity is held by domestic residents.

Table 7.4 provides estimates of equity portfolio weights for US, Japanese and UK savers. French and Poterba also estimate the additional return that savers must expect in order to justify the low level of international diversification. As the table shows, US savers hold almost 94 per cent of their portfolios in domestic equities. The estimates of the return on an internationally diversified portfolio are compared with estimated returns on portfolios with distributions comparable to British, Japanese and US investors. To justify the low level of international diversification, US savers must anticipate a return on their domestic equity holdings that exceeds the actual return by almost 1 per cent. UK savers, due to a smaller overall equity market, have the most internationally diversified portfolios of the three nations. To justify 82 per cent of their portfolio in UK equities, however, UK savers must anticipate a return on their domestic holdings that exceeds the actual return by more than 4 per cent.

Table 7.4 Equity portfolio diversification (\%)

\begin{tabular}{lccc}
\hline & United States & Japan & United Kingdom \\
\hline United States & 93.8 & 1.3 & 5.9 \\
Japan & 3.1 & 98.1 & 4.8 \\
United Kingdom & 1.1 & 0.2 & 82.0 \\
France & 0.5 & 0.1 & 3.2 \\
Germany & 0.5 & 0.1 & 3.5 \\
Canada & 1.0 & 0.1 & 0.6 \\
& & & \\
Excess returns required to justify domestic share of equity portfolio \\
(as per cent) & 0.9 & 2.5 & 4.4 \\
\hline
\end{tabular}

Source: French and Poterba (1991).

French and Poterba conclude that these low levels of international diversification are not due to any national or institutional constraints. The three countries in their study have few if any capital controls in place today, and tax differences and transaction costs are also very small for these nations. The authors conclude, therefore, that the low levels of diversification are due to savers' tastes. They speculate that savers perceive a greater degree of risk in foreign equity markets because they are less familiar with those markets than they are with domestic equity markets. 


\section{International Money Markets}

International money markets are markets for cross-border exchange of financial instruments with a maturity of less than one year. Although traders exchange a number of different types of instruments in international money markets, foreign exchange instruments are most actively traded. As noted earlier, the international capital markets have experienced considerable growth since the early 1970s. The international money markets, however, have experienced astounding growth. Economists periodically estimate the volume of transactions in the foreign exchange markets based on surveys of the largest banks and foreign exchange trading firms. Current estimates of the daily activity on the foreign exchange markets indicate that the daily turnover is approximately $\$ 1.25$ billion. On average, the daily volume of the foreign exchange market approximates two months of activity that occurs in the New York stock exchange market.

The international money markets are comprised of a number of financial instruments other than spot and forward exchange contracts. These instruments include short-term international bank, government and corporate notes, and international commercial paper. Because transactions among large banks constitute the bulk of international money market exchanges, we can use reports of these banks' cross-border asset and liability positions to estimate the size of the market. Table 7.5 provides data on the cross-border positions for December 1997 and the change in cross-border positions for the year 1997. As shown, reporting banks had over $\$ 8$ trillion in both outstanding assets and liabilities. The change in these positions for the year 1997 was approximately $\$ 0.5$ trillion.

Table 7.5 also shows the dominance of the industrialized countries' banks in international money markets. Cross-border positions of the industrialized countries represents over 78 per cent of the total. The dominance of the US dollar, as discussed by Daniels and Davis in Chapter 9, is also apparent with the dollar denominating over one-third of outstanding positions.

\section{Capital Flows and Developing Economies}

Arguably the most important feature of the international financial markets is the increased volume of financial flows between nations. Indeed, the most striking feature of the 1990s is the increased volume of flows to the emerging countries. Figure 7.1 illustrates the rise in total net private capital flows for the emerging economies, distinguishing between official net direct investment flows and portfolio flows. As shown in the figure, net private capital flows to the emerging economies have risen a dramatic 415 per cent. 
Table 7.5 Reporting banks' cross-border positions, December 1997 (US\$ billions)

\begin{tabular}{lcr}
\hline & December 1997 & Estimated change \\
\hline Assets & & \\
Industrial countries & 7123.6 & 1019.4 \\
$\quad$ US dollar & 3178.1 & 461.3 \\
$\quad$ Other currencies & 3945.5 & 558.1 \\
All other countries & 1914.7 & 137.3 \\
$\quad$ Total & 9038.3 & 1156.7 \\
& & \\
Liabilities & & 963.6 \\
Industrial countries & 6948.7 & 419.3 \\
$\quad$ US dollar & 3215.7 & 544.3 \\
$\quad$ Other currencies & 3733.0 & 183.2 \\
All other countries & 1892.2 & 1146.9 \\
$\quad$ Total & 8840.9 & \\
\hline
\end{tabular}

Source: Bank for International Settlements.

As learned from the 1994-95 Mexican financial crisis, it is important to recognize the proportion of net private capital flows that are portfolio investment. Portfolio investment, often referred to as 'hot money', can reverse direction quickly, leaving a nation's financial sector in an illiquid position. (See Chang and Velasco (1998) for an excellent review of the Asian liquidity problem.) Figure 7.1 shows that for the emerging economies, the proportion of net portfolio investment increased from 1990 through 1994, representing a sizable overall proportion in 1993 and 1994. Much of this is reflected in portfolio flows to the Western Hemisphere, or countries such as Mexico, Brazil and Argentina. The sizable decline in portfolio flows in 1995 is also reflected in the Western Hemisphere data as these flows reversed following the Mexican financial crisis, resulting in a drop of $\$ 68.3$ million in 1995 alone, representing a 112 per cent decline and overall negative net portfolio flows for the region.

Figure 7.1 also illustrates that the proportion of net portfolio flows to total private capital flows differs widely across the various regions. For the Middle East and Europe, net portfolio flows account for 42 per cent of total private flows, while it is a mere 8 per cent for the transitional economies. Net direct foreign investment flows as a percentage of total net private flows range from 58 per cent for the transitional economies to a scant 7 per cent for the Middle East and European economies. 


\section{RISK AND REGULATION}

As described above, the growth and globalization of financial markets and institutions has brought about a vast number of new opportunities for savers and borrowers. It has, however, also generated new risks and magnified existing risk potential. The four types of risk considered here, in the context of globalization and technological advance in financial instruments, are: Herstatt risk, legal risk, operational risk and systemic risk. There are a number of other types of risk that could be explored, such as liquidity risk and settlement risk, but these would be beyond the confines of this chapter. Hence, only the most obvious sources are discussed, in brief.

\section{Risk}

More than two decades ago the impact of Herstatt Risk, or settlement risk that spans time zones or systemic risk, was felt. In 1974, German banking regulators closed the failed Herstatt Bank at 3.30 p.m., after the bank had received European foreign exchange payments but before it made required payments to US banks. Because the US banks did not receive their anticipated payments, they were, in many cases, unable to fulfil their own obligations. By the time the entire event unwound, US banks had lost as much as $\$ 200$ million dollars.

Systemic risk, settlement or credit risk that spills over and effects third parties, has been a significant concern following the Mexican crisis of 1994 and the 1997 East Asian financial crisis. An important aspect of increased globalization is the transmission of shocks and the potential for contagion. As financial markets become more integrated, the transmission of shocks becomes possible and can even be magnified. Such was the case in the US stock market crash of the 1980s. Because of intertwined markets, the crash spilled into exchanges across the globe.

As demonstrated in the previous section, there has been a dramatic increase in short-term portfolio flows, particularly to the emerging economies. Many of these emerging nations have financial and banking sectors that are underdeveloped, not regulated and not properly supervised. When positive, these net inflows can put upward pressure on a nation's currency and on domestic inflation. On the other hand, they also represent a lower-cost form of financing, hence lower interest rates, and stimulate a nation's economy.

Portfolio flows can, however, reverse direction at rates that quickly exhaust the cumulative buildup of years of inflows. In an economy with an underdeveloped financial sector, these outflows may result in an illiquid banking system and put downward pressure on the nation's currency. Under a fixed exchange rate regime, the government is faced with opposing problems: the banking system needs additional liquidity while the exchange rate regime 
Emerging economies

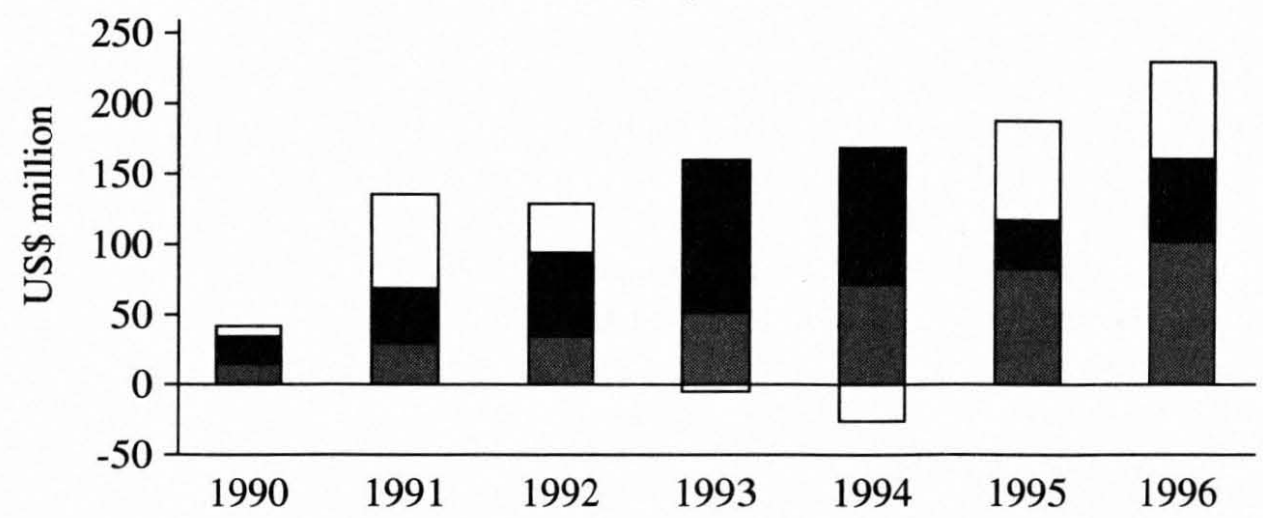

Asia

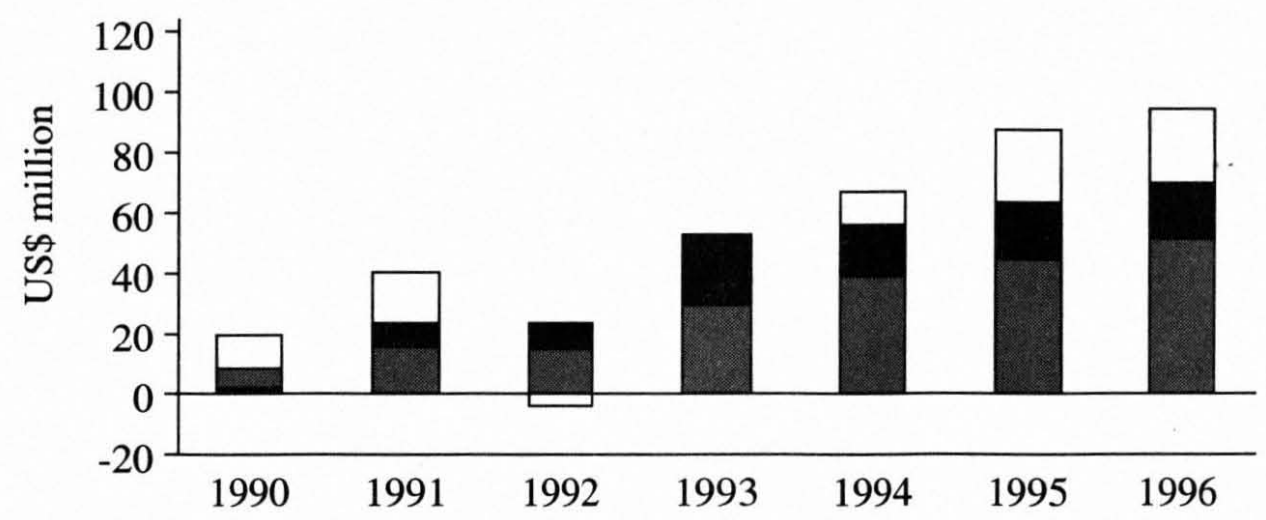

Transitional







Source: Developments and Prospects In Emerging Markets, International Monetary Fund, 1998. IMF country classification groups can be found in the introduction to the statistical annex of the World Economic Outlook.

Figure 7.1 Net private capital flows to emerging economies, 1990-96

requires higher interest rates. These hot money flows appear to occur regionally as opposed to nationally, with one country serving as the trigger for a regional crisis (Mexico and Thailand, for example). This is the type of problem seen in the recent financial and currency crises (see Glick (1998) for a survey of the literature in this area). Empirical work by Glick and Rose (1998) indicates that currency crises affect regions or 'clusters' of nations through international trade channels.

As the financial markets have evolved, new and highly sophisticated financial instruments have been introduced. The use of these instruments often 
becomes widespread before appropriate domestic regulators and corporate managers fully understand their risks and benefits, thereby increasing operational, or management risk, and legal risk, the risk that the contract cannot be enforced by a legal body. The 1995 collapse of Barings Bank illustrates operational risk. The same day that Peter Baring had to ask the Bank of England to intervene, and the day after the trader involved in the derivatives fiasco, Nick Leeson, faxed in his resignation, Barings was to announce and award company bonuses, including a bonus to Leeson in the amount of $£ 450,000$. The total losses to Barings is estimated to be $£ 927$ million. (See Kuprianov (1995) for case studies on Barings PLC and Metallgesellschaft AG.)

A final aspect considered here is the impact of increased globalization, competition and technological advances on bank structure. Regulatory arbitrage, the practice of establishing foreign offices to avoid domestic regulation, has increased dramatically due in part to technological advances in banking. Globalization and competition have led to increased merger activity and the creation of 'mega' banks. Both activities undermine the attempts of sovereign governments to regulate and supervise national banking institutions.

\section{Global Regulation}

How should sovereign governments and international organizations respond to the risks of increasing financial integration? It is important first to distinguish between international financial liberalization and financial regulation. Liberalization is the opening up of the financial market to foreign participants, increasing competition and opportunities for domestic banks. Regulation is the governing of the financial sector in order to improve its operation of financial intermediation. Obviously, and as evident in the recent financial crises, appropriate regulation and supervision is important for the domestic financial system to absorb and channel in an economically efficient way the inflows and outflows of capital that result from financial liberalization.

\section{Views of government intervention}

One view of government intervention in the financial sector is that financial intermediation is inherently an unstable business the fortunes of which rise and fall with the business cycle and that financial markets may have inherent imperfections. Hence, government regulation and safety nets are required to prevent periodic banking collapses.

In line with this view, Von Hagen and Fratianni (1998) identify three main reasons for financial regulation. The first is that small depositors find it too costly to continuously monitor the activities of intermediaries. Hence, small depositors need protection from the risk of bank failure. The second is that 
regulation is required to prevent large withdrawals from one bank that might affect the entire industry, or to prevent contagion. The final reason is to preserve the integrity of the payments system. The authors assert that these types of banking regulation involve the reallocation of risk and therefore wealth among market participants. In a global setting this reallocation can become quite complex as sovereign governments wish to protect domestic residents over foreign residents.

Another view is that regulation that eliminates competition, and the existence of safety nets, creates a moral hazard problem and may actually be responsible for recent banking crises. This second view has been used extensively to build a critical case against the necessity for international organizations such as the IMF. It has played particularly well on the floor of the US Congress which begrudgingly approved new funds to the IMF.

\section{Regulation and supervision: new or old institutions?}

In spite of recent criticism, there have been a number of well-placed initiatives and actions taken in response to the risks described above. Examples are the Lamfalussy Report, a 1990 G10 initiative that outlined the legal responsibilities of any intermediary undertaking a large volume wire transfer; the Basle Capital Accord for capital adequacy standards; cross-border banking principles for consolidated supervision; risk management guidelines for derivatives trading and core principles for effective banking supervision.

Many of these initiatives resulted from G7 directives. The Halifax and Lyon Summits, in particular, addressed the global financial situation. (See the excellent volume by Kenen (1996) and the summary by the BIS (1999). Directives to the IMF included a request to the IMF to develop procedures to provide faster access to IMF credit with strengthened conditionality, to develop standards for data availability and to intensify surveillance beyond Article IV policy reviews. The response was an emergency financing mechanism, the Special Data Dissemination Standards, and publication of Article IV reviews for those countries wishing the reviews to be public.

The G10 was asked to double the credit facilities available to the IMF and to review procedures that might prevent or resolve financial crises. The G10 responded with a new arrangement that doubled available IMF credit and, as a first-step, conducted a survey of market participants and domestic regulations in numerous countries. Based on the results of the survey, the G10 emphasized market-based governance and that countries should not expect bailouts the 'size of Mexico'.

Arguably most important, in regard to government intervention, is the problem of IMF bailouts. As is frequently argued, unlimited IMF bailouts increase the moral hazard of lending and borrowing activities. Jeffery Sachs (1998, p. 24) argues that the IMF worked 'mightily and wrongheadedly' to 
make the world safe for 'naive 25-year-old investment bankers who do not know much about world politics'. Bailouts such as that in East Asia should cease.

Recent words of the G8, particularly at the Birmingham Summit, indicate that nations should not expect unlimited bailouts. It appears, however, that the IMF is continuing to approach problems as it has in the past, and thus IMF actions say otherwise. It is vital that the G7/G8 formulate a coherent and consistent approach to bailouts in future financial crises. The G7/G8 and the IMF must break the expectations they helped create. It is disappointing that the strongest statement the leaders could offer at the Birmingham Summit was that, 'It is also important to ensure that the private sector plays a timely and appropriate role in crises resolution.' US influence is strong in these organizations and US officials need to play an activist role in setting the agenda.

In the long term, policy-makers should rethink completely the role of and even the necessity for the IMF and the World Bank. They must first realize that the IMF is not technically equipped to deal with the types of financial crises that occur in the post-Bretton Woods era. Due to the increased integration of capital markets, the current crises have been fast developing, financial in nature and beyond the capacity of the fund and other existing international organizations. As an example, the current IMF Manual For Country Economists states: 'A country will require IMF assistance when it is having balance of payments difficulties or, in other words, when the normal inflow of external savings is not sufficient to finance its resource gap, which is defined as the difference between domestic savings and domestic investment.'

In addition, the current approach to fund conditionality is counterproductive. Sachs (1998, p. 25), states that:

This process [conditionality] is out of hand. It has undermined political legitimacy in dozens of developing countries, especially since the IMF is often happy to conspire with governments to make end runs around parliaments in the interests of 'reform'. The contents of IMF programmes are too flawed to be a standard of good or poor performance. Markets realize this, so IMF programmes do less and less to rally them.

Finally there must be further discussions on supervisory coordination. Primarily an initiative of Canadian Finance Minister Paul Martin, the issue should be expanded to include regulatory coordination in order to reduce regulatory arbitrage. In contrast to the Martin initiative, however, this should not lead to a new supranational body composed of governmental agents. It should be delegated to an agency with the greatest comparative advantage, perhaps the London Club or the Bank for International Settlements. None the less it should be a market-based approach as has been pursued thus far, since 
in today's financial environment, operational risk is greater than market risk. Bank management must therefore be involved.

\section{CONCLUSION}

Financial intermediaries play an extremely import role as they channel savings to borrowers and help finance domestic investment. The solvency of a nation's system of banks is critical for the stable flow of capital and continued growth and prosperity. Unfortunately, history has shown that financial systems and intermediaries are quite fragile. As one might suspect, given the increase in international capital flows, very few national capital investment projects are financed purely by domestic intermediaries. Given the heightened level of integration, a nation's system of intermediaries is now exposed to new sources of risk. These risks must be measured and managed in a global context, presenting challenges for financial managers and regulatory authorities and creating a need for coordinated efforts. US policy-makers should take an active role in ensuring that a market-based approach continues to be pursued in addressing these challenges.

\section{REFERENCES}

Altunbas, Yener and Philip Molyneux (1996), 'Cost economies in EU banking systems', Journal of Economics and Business, 48, 217-30.

Caiola, M. (1995), A Manual For Country Economists, Training Series Number 1, Volume 1, Washington, DC: International Monetary Fund.

Chang, R. and A. Velasco (1998), 'The Asian liquidity crises', Federal Reserve Bank of Atlanta Working Paper 98-11.

Crockett, Andrew (1997), 'Why is Financial Stability a Goal of Public Policy?', in Maintaining Financial Stability in a Global Economy: A Symposium Sponsored by the Federal Reserve Bank of Kansas City, Jackson Hole, Wyoming: Federal Reserve Bank of Kansas City, pp. 7-36.

Daniels, Joseph and David Van Hoose (1999), International Monetary and Financial Economics, Cincinnati: SouthWestern Publishing.

Eatwell, J. and L. Taylor (1998), 'International capital markets and the future of economic policy', Working Papers Series III, Centre for Economic Policy Analysis, New School for Social Research, New York.

The Economist, (1998), 'Capital Controversies', 23 May, p. 72.

Eichengreen, Barry, Michael Mussa, Giovanni Dell'Ariccia, Enrica Detragiache, Gian Maria Milesi-Ferretti and Andrew Tweedie (1999), 'Liberalizing capital movements', International Monetary Fund, Economic Issues, 17.

French, Kenneth and James Poterba (1991), 'Investor diversification and international equity markets', American Economic Review Papers and Proceedings, 81 (2), $222-6$. 
Glick, R. (1998), 'Capital flows and exchange rates in the Pacific Basin', Federal Reserve Bank of San Francisco Economic Letter, 98-22.

Glick R. and A. Rose (1998), 'How do currency crises spread?', Federal Reserve Bank of San Francisco Economic Letter, 98-25.

Kenen, P. (ed.) (1996), From Halifax to Lyons: What Has Been Done about Crisis Management? Essays in International Finance, 200, International Finance Section, Princeton University.

Kuprianov, Anatoli (1995), 'Derivatives debacles: case studies of large losses in derivatives markets', Federal Reserve Bank of Richmond, Economic Quarterly, 8 (4), 1-39.

Lindgren, C., G. Gillian and M. Saal (1996), Bank Soundness and Macroeconomic Policy, Washington, DC: International Monetary Fund.

Organization for Economic Cooperation and Development (1997), Financial Trends, Paris: OECD.

Sachs, J. (1998), 'Global capitalism: making it work', The Economist, 23-5.

Von Hagen, J. and M. Fratianni (1998), 'Banking Regulation with Variable Geometry', in B. Eichengreen and J. Frieden (eds), Forging an Integrated Europe, Ann Arbor: The University of Michigan Press, pp. 159-84.

Williamson, John, and Molly Mahar (1998), 'A survey of financial liberalization', International Finance Section, Princeton University, Essays in International Finance, 211. 